\title{
The internet and education in the developing world - hopes and reality
}

\author{
Srinivasan Ramani
}

\section{Correspondence:}

Ramani.Srini@gmail.com

International Institute of Information

Technology, Bangalore 560100,

India

\section{Springer}

\begin{abstract}
Information and communication technologies have made a major impact on education. This raises hopes in countries like India which are undergoing rapid growth in their educational efforts. Will Information and Communication Technologies create a revolution in the education sector? What can we expect in the way of impact due to the spread of access to the Internet? Will Internet access over the mobile phone make rapid advances possible in rural areas? What evidence is available to judge popular claims and predictions regarding dramatic growth of Internet usage as a result of the widespread use of cell phones? Can we identify the impeding factors that limit progress in using technology for education at middle schools, secondary schools and higher secondary schools?

The paper addresses these questions, focusing mainly on Indian data and surveys progress in the spread of access to the Internet, including access using cell phones. It presents information on expenditure levels to offer insight into relevant socio-economic factors. It discusses the problem of language and the nature of content available over the World Wide Web. The whole effort reported in this paper is to get a realistic view of the current and potential impact of the Internet and Communication Technologies on education in India. Evangelists of technology have a way of creating unsustainable hopes by ignoring social and economic reality, and therefore a critical examination of available information is necessary.

The paper concludes by discussing technologies and initiatives worth considering for ameliorating the situation mentioned above.
\end{abstract}

Keywords: ICT; Internet; Mobile phones; Word Wide Web; Access devices; Tablets; Languages; Socio-economic factors; Human machine interface; Smart Phones

\section{Introduction}

Every major development in technology triggers hopes in developing countries in regard to its potential impact on education. Internet technology has significantly contributed to furthering education in the world. The World Wide Web and search engines have made information on demand a reality. Low cost models for supporting learning, such as Massive Open Online Courses, are kindling new hopes in developing countries. Lower cost Internet access devices, such as tablets, phablets, and smart phones have addressed the problem of device affordability to a significant extent. The widespread use of cell phones opens up the possibility that many or most of them could be used as windows to the world of information and knowledge over the Internet.

(C) 2015 Ramani; licensee Springer. This is an Open Access article distributed under the terms of the Creative Commons Attribution License (http://creativecommons.org/licenses/by/4.0), which permits unrestricted use, distribution, and reproduction in any medium, provided the original work is properly credited. 


\section{Research questions}

Is the stage set for a major revolution in the way technology can facilitate education in developing countries? What does published information from credible sources indicate about reality on the ground? Does rapidly evolving technology leave behind sections of the population, or is there uniformly good use of the new tools to promote learning? What should we expect from the future, and what should we do to overcome problems identified?

\section{Background and literature review}

The techno-centric view of development emphasises such phenomena as the rapid spread of technology, its adoption by the young and reducing costs. This view often leads to the creation of hope that such impact of technology by itself can revolutionize education. Warschauer et al. (2002) wrote a pioneering analysis of a case where such hopes had been created. In many cases such hopes turn out to be false, leading to missed opportunities for the citizens. His concludes his paper by emphasizing the importance of re-orienting "the focus from that of gaps to be overcome by provision of equipment to that of social development to be enhanced through the effective integration of Internet and Communication Technologies (ICT ${ }^{\mathrm{a}}$ ) into communities and institutions". Keniston et al. (2003) discussed digital divides separating those who benefit from the Internet and those who do not. They discuss the divide between haves and have-nots in a socio-economic sense. They also discuss the divide resulting from people finding inadequate content in their own language on the Web. These two divides will be discussed in detail in the following pages, using recent Indian data. Keniston et al. (2003) page No. 2 have commented on "optimistic hopes and fantasies" that technological revolutions create. New phenomena such as the introduction of smart phones and tablet computers into developing countries have created such hopes and fantasies. The current paper will also discuss the impact of smart phones and tablet computers and analyse it from the point of view of the research questions defined earlier.

\section{Growth of mobile phone subscriber base}

Growth in the use of mobile phones in India has been quite rapid, and has been accompanied by the availability of relatively inexpensive smart phones. A document published by the Telecom Regulatory Authority of India (TRAI 2012, page No. xi) states "From 2001 to 2011, the total number of telephone subscribers has grown at a compound annual growth rate (CAGR) of 35 percent. The comparable rates in the 1980s and 1990s were 9 percent and 22 percent, respectively". TRAI (2013) adds that the total number of telecom subscribers (Wireless + Wireline) as of 31 March 2013 was $898^{\mathrm{b}}$ million. What is surprising is that out of this 898 million, wireless subscribers alone account for 868 million.

The figure of 868 million phones in use by a population of 1210 million (Census 2011) does not mean that 868 million Indians use mobile phones, as many users have more than one phone in service. TRAI (2013) gives overall teledensity ${ }^{\mathrm{c}}$ in India as 73 and rural teledensity in India as 41 . The growth in teledensity has been truly impressive. (TRAI 2012) points out that overall teledensity had been only 4.3 in March 2002; rural teledensity had been at only 1.2 . 


\section{Growth of the internet subscriber base}

Telecom Regulatory Authority of India, TRAI 2012, states that Internet and broadband subscribers constitute only a small fraction of the population. However, the number of people capable of accessing the net through mobile phones is substantially higher if wireless data subscription through mobile is an indication. Out of the 91.8 million people using $^{\mathrm{d}}$ Internet in India, there were only 18.7 million fixed Internet subscribers in 2010, as per (TRAI 2012).

Telecom Regulatory Authority of India, TRAI (2013) gives figures as of March 31, 2013 as follows:

Total number of Internet subscribers: 165 Million.

Internet subscribers excluding those who access the Internet using wireless devices: 22 Million.

Internet subscribers who accessed the Network using wireless devices: 143 Million.

Meeker (2014) of Kleiner Perkins Caufield Byers made a presentation in May 2012, offering the following observations, among others:

- India has 121 million Internet users. The increase in their numbers during 2008-2011 had been 69 million. In comparison, the growth in the US had been 15 million.

- There were 39 million $3 G$ subscribers in India, growing at $841 \%$ year on year. Compare with $115 \%$ of China and the $31 \%$ of the US.

- The percentage of Internet traffic carried by cell phones in India had overtaken Internet traffic carried by desktops by April 2012.

However, whether such growth has had any significant impact on education is highly arguable. A number of researchers had anticipated a significant role for smart phones in educational technology, for instance, Yerushalmy et al. (2004) and Thornton and Houser (2005). However, India has not seen any major use of smart phones in mainline school education. One reason for this might be the cost barrier that frightens the bulk of Indian students away from using cell phone access to the Web.

Kumar (2011) refers to the fact that one could pay a small amount to get pre-paid web access. Is this true? In reality, commercial costs for downloading information are frightening to students using prepaid mobile plan packages. A typical service provider charges them Indian Rupees (Rs) 0.03 per $10 \mathrm{~KB}$ of data transfer and this translates to a rate of Rs. 3000 (roughly US\$ 50) for a gigabyte of data. Naïve users do not usually understand these calculations and a few make the mistake watching a few videos and see their meagre prepaid deposits disappear very quickly. The cost of downloading a 27 page article from the Wikipedia can be Rs 18 to the student at the rates mentioned above. In comparison, the researcher downloads the same article at less than one-tenth of that cost, because he has committed to a Rs. 250 per month data plan from his cellular service provider.

(TRAI 2012), quotes Bhide (2010) to say that the $3 G$ spectrum auction combined with the bid values for broadband wireless access licenses yielded more than Rs. 100,000 crore in 2010 (roughly equivalent to US\$ 21 Billion at that time) to the Government of India, amounting to approximately 1 percent of the Gross Domestic Product of the country. Mankotia et al. (2015) has reported that the spectrum 
auction for 2015 has earned the Government of India Rs. 109,800 crore (roughly equivalent to US \$ 17.5 Billion). Cellular telephony companies that have paid such a large sum must obviously expect to earn commensurate incomes.

Krishnan and Ramani (2015) have discussed the growth of smart phone usage in India using slightly older data; they have also described the impact of ICT in India on engineering, technology and related science education at the university level.

\section{Inexpensive internet access devices}

A $\$ 100$ mobile phone usable as a Web access device is obviously more attractive on economic grounds than a Laptop or Notebook costing \$250 upwards. Tablets and Phablets offer other levels of trade-off. Noting the importance of low cost Web access devices, the Government of India has taken steps to make low cost tablets available to Indian students and teachers according to the Press Information (2012). However, a project to serve a large student population by making available to them a new device like this is fraught with its own complexity. The story of this project involves three versions of the device - Aakash 1, 2 and 3. The technology used in the device and comparison with competing devices requires a separate article to do justice to the topic. The Wikipedia article (Aakash 2014) is a useful summary.

\section{Language of the users}

Students can efficiently use the Internet to acquire knowledge and information only if content is available in a language in which they can read well. English continues to be the most widely used language world-wide for creating and for accessing content on the Web. (W3Tech 2014) indicates that 55\% of the websites on the Internet show English as the language of their content. Indian languages, including Hindi and Tamil, are among the languages accounting for less than $0.1 \%$ of the websites each.

Times of India (Times 2010) quoted data from (Census 2001) and said that English was the primary language for barely 230,000 Indians at the time of the census, and that more than 86 million listed it as their second language and another 39 million as their third language. Census (2001) reported that $10.35 \%$ of the population speaks English as a secondary language. There were 88.5 million Secondary School students in India in 2001 (Census 2001), covering the age group from 14 to 18. Are high school students far more likely to be English speakers than their parents? This can be judged by information given by a Government Order from Andhra Pradesh State of India (Andhra Pradesh 2008), which states that $95 \%$ of private schools offer English as a medium of instruction, but that private schools are concentrated in the big cities. $98 \%$ of government funded schools in the state use only the language of Andhra Pradesh - Telegu as the medium of instruction. Schools in which English is not the medium of instruction usually teach English as a second or third language. Students typically study this as one subject out of six. The author believes that the situation is similar in most of the other states of India.

The Indian Reader Survey (IRS 2012) of newspaper readers presents some relevant information, which is summarized below. Table 1 gives information regarding the number of Indian newspaper readers ${ }^{\mathrm{e}}$ as of the last quarter of 2012.

Out of 1222 million Indians, those that read a daily newspaper are approximately 153 million only; the top 10 dailies in a language cover a high percentage of readers in that 
Table 1 Readership of English and Indian language newspapers in India (in millions)

\begin{tabular}{lll}
\hline Readers of top $\mathbf{1 0}$ English dailies & Readers of top $\mathbf{1 0}$ Hindi dailies & $\begin{array}{l}\text { Readers of top } \mathbf{1 0} \text { dailies } \\
\text { in other Indian languages }\end{array}$ \\
\hline 19.7 & 71 & 62 \\
\hline
\end{tabular}

language. Hence, only 19.7 million out of 1222 million Indians read English newspapers.

\section{Results and discussion}

Suitability of mobile devices in rural areas

All mobile computing devices and Web access devices, including Laptops and Notebooks, offer certain advantages over PCs. Firstly, having a desktop is not an option for a student not having a desk, or even room for a table in the dwelling! Secondly, having a PC does not help when electricity is not available for hours at a time everyday due to "power-cuts". (Chaurey et al. (2004), page 1697) refer to "continuous power cuts to the tune of 16-20 h for 20 days in a month is a common occurrence (as determined by the primary survey findings)". In comparison to PCs, all mobile devices have their own stored power that lasts several hours and they do not require table space. Further, as mentioned in the Literature Review Section, the lower cost of mobile devices is a major attraction. Yet another important factor is that a mobile device does not require coping with complex wiring between several small units. Imagine a PC with an Uninterruptible Power Supply ${ }^{\mathrm{f}}$, a Keyboard, a display, a modem and a mouse. It is a serious challenge to an inexperienced user to diagnose the cause of any problem arising in such a setup. In comparison, mobile devices technology packages the multiple devices mentioned above into one unit, eliminating problems posed by external wiring.

The smaller screen size and poorer text entry facilities make the phone option a poorer option for web access. Tablets are a potentially valuable tool for use in many developing countries. However, project planners face a variety of issues. Should they specify an ideal tablet for the task and expect manufacturers to build a new product to meet the specs; or should they distribute funds to stimulate purchase of a variety of devices? A design specified by the government is not attractive to major manufacturers who are reluctant to design a low cost product for fear that it will cannibalize their market for more expensive devices that are sold to those who can afford them, on the basis of fancier and fancier designs. The mainline tablet is designed for high quality reproduction of videos and photographs.

Every design effort requires a choice to be made between options. One would assume that the design of a low cost tablet for educational use in developing countries would avoid expensive features and focus on primary requirements. However, many designs for "low cost" access devices in developing countries have failed because they ended up trying to compete with multi-purpose tablets designed for well-off users.

No discussion of access devices in education can be complete without covering the case of the "One Laptop per Child (OLPC)". A review from the educationists' point of view can be found in (Warschauer and Ames, 2010). Their paper describes the faith that the supporters of the OLPC effort had in students' ability to learn about using the Laptop on their own and in teaching one another. They point out 
on page 35 of their paper cited above that pilot programs, staged implementation, monitoring and formal evaluation were not considered relevant by the OLPC project leader, Nicholas Negroponte, because he had argued that the benefits of the device were obvious.

The conclusion of Warschauer and Ames (2010) is that "OLPC represents the latest in a long line of technologically utopian development schemes that have unsuccessfully attempted to solve complex social problems with overly simplistic solutions".

It is necessary to note that no large scale use of tablets by school students has been observed in India as yet. Students in metropolitan cities, particularly those coming from an elite socio-economic background, may use tablets; but the devices are not used even by such students primarily for learning.

\section{Teacher versus machines}

Serious doubts have often been expressed in literature about the teacher playing an effective role in the education of students in developing countries. Sadanha (2012) page 5 refers to the "sea of unqualified teachers at the primary and secondary levels" in the context of teaching English at school level. She also refers to the extremely limited funds available for the purpose. (Negroponte (2006), page 26) has said, "In some countries, which I'll leave unnamed, as many as one-third of the teachers never show up at school. And some percent show up drunk."

The level of education and training of teachers and their poor attendance at school are undoubtedly real problems in parts of rural India, but the students in such areas cannot do without teachers. Most of these students suffer some combination of several handicaps: poverty, urban/rural divide, caste, gender, language, religion, and parents who are functionally illiterate. Krishna (2013) describes the nature of handicaps that these factors create in educational opportunities in general. To argue that students so severely handicapped should teach themselves how to use a laptop or tablet for online learning is day dreaming. Warschauer (2002) has described the disappointing results of an experiment that tried to get students to teach themselves using computers, with no help from teachers or anyone else. To argue that one can overcome the problems arising from poor quality of teaching in rural areas by using technology alone is absurd; it is like arguing that malnutrition can be tackled merely by using vitamin and mineral supplements! Such supplements cannot substitute for real food!

If teachers do not have a good educational background and training and their attendance at school is not satisfactory, these problems have to be rectified with high priority. Information Technology is not a silver bullet to eradicate all problems of the educational system.

\section{The language barrier}

The literature review section presented data to show that 150 million Indians, that is approximately $12.5 \%$ of the population read dailies and that only $1.6 \%$ of Indians read their dailies in the English language. This is an indicator of what Indians would prefer to use as a language for acquiring information knowledge and skills over the Internet. Dailies offer information and knowledge. They are a major source of information and knowledge outside the classroom. Therefore, it is reasonable to expect readership 
statistics of newspapers to tell us about user preferences of language for information/ knowledge access online.

Imagine a taxi driver who is asked to turn right at the next traffic signal; if he replies saying that it is a one-way street, he can be said to be a speaker of English. However, if he has a family member who has suffered a stroke, is he likely to read a library book, a web article or a magazine article in English to acquire information on the problem? Is he likely to benefit from such information in English? The contention of this paper is that the typical Indian would require such information in his mother-tongue, and that the availability of such information in Indian languages is very unsatisfactory. It is also worth questioning if teaching English as one of five or six subjects equips the typical Indian student to profit from information on the Web in the English language. A test of this ability could be to give printed information downloaded from the Web and test for its comprehension. Ideally, the topics should be chosen for relevance to the students being tested and the material should be selected for readability.

\section{Computer related skills, aspirations and the language divide}

Most parents who want their children to learn to use a computer effectively also want them to improve their competence in the English language. They expect their children to get better jobs as a result. They recognize that computer related skills are important to office work, whether in government offices, banks, or in companies. They understand that, as things stand in India at present, command over English is valuable to progress in life. However, enrolling one's children in English-medium schools turns out to be counter-productive if the school is not effective in teaching English well enough. When children do not have anyone at home to help them learn English, studying in the English medium becomes a big burden to them. If standards of teaching are poor, they end up learning neither English nor any of the subjects they are taught through English!

Another source of disappointment is faced by students who study in a "vernacular medium" and hope to transfer easily to English medium classes in college. Sadanha (2012) presents the poignant real-life story of a Hindi-educated twenty-two-year-old, who joins an engineering college near Delhi. He is from a small town and has studied English as one of his subjects until the tenth grade, but his medium of instruction has been Hindi. He ends up committing suicide, leaving behind an explanatory note. The cause of his tragic end turns out to be undue pressure from his English-medium courses; he did not want to burden his parents with the costs of English coaching to help him prepare better. This disturbing story, covered in the Hindi and English print media, highlights the long-standing divide between students who come from Englishmedium backgrounds and those who come from "vernacular" ones. Puri (2008) has analysed this phenomenon in considerable depth.

Mukherji (2012) reported that over twenty million Indian students in grades I - VIII study in English medium schools. The number of such students has grown by $274 \%$ since 2003-04. It reported that private schools were not the only ones providing English medium education. Government schools in Jammu and Kashmir and in the Punjab were also adopting the English medium for use in government schools. However, it quotes Vinod Raina, an architect of India's "Right to Education Bill", saying "That 
government schools are turning to English medium does not in any way mean that either teachers or students at these schools can speak a word of English!"

\section{Content in Indian languages}

Consider a youngster hoping to get a job as an assistant in a photographic studio, and a student who has completed nursing school and is preparing for a job interview, who wants information on anaphylactic shock. Can they find the required information in their own languages? Some of this information, such as the one on anaphylactic shock, may be in printed form in text books. Some information, such as the one on digital cameras, could be in printed form in magazine articles or in expensive books in English. However, the focus of the following discussion would be on supplementary ${ }^{\mathrm{g}}$ information available online.

Google searches, carried out Aug 7, 2014 yielded the following results:

Query: Language: Hindi "anaphylactic shock"

Hits 1-8 offered dictionary meaning in Hindi. The ninth offered a translation into

French, Stroke Anafilactico! The tenth offered an article in English on how to treat anaphylactic shock in a dog.

Query: Language: Hindi "digital camera"

Hits 1-4 offered dictionary meanings of "digital camera" in Hindi. The fifth was an English article on a GSM ${ }^{\mathrm{h}}$ phone, and the following six articles were irrelevant.

Query: Language: Hindi stroke

Hits numbered 1 and 3 were dictionary meanings in Hindi. The eleventh was an advertisement for a book on Stroke Paralysis. Hit No 2 (Stroke) was a well translated article in Hindi about stroke. It advised the reader that if he felt any signs of stroke, he should call 911! No wonder, it was an article published by the National Institutes of Health (NIH) in the US. Six other hits were irrelevant. One other hit was a downloadable version of the NIH document mentioned above.

Query: Language: Tamil "anaphylactic shock"

The first hit was a translation by Google Translate which offered

“பிறழ்ந்த அதிர்ச்சியால்"; this offered no meaningful information to the author, a Tamil speaker. The next ten hits were English articles.

Query: Language: Tamil "digital camera"

The first hit was a 11 minute video from YouTube which seemed to be an advertisement for a spy cam in Tamil. The following 10 hits were English articles.

Query: Language: Tamil stroke

The first 11 hits comprised of two dictionary meanings, a YouTube video in Tamil (Heart and Stroke 2007) lasting 36 seconds listing the warning signs of stroke, and nine English articles dealing with the different topics referred by the English word "Stroke".

\section{Using common tools for text entry, transliteration and translation}

Part of the problem in creating information in Indian languages is that standard input techniques have not become very popular. Many Indian scripts use a two dimensional arrangement with complex diacritical marks, called "matras" attached above and below 
the line of basic characters. Several decades of work has gone into complex keyboards for handling these scripts (Sinha and Raman 1980), (Shanbhag et al. 2002); however, keyboards for Indian scripts are not in wide use except for government related work.

Innovative new tools such as Google input tools and Google translate make it easier for native speakers of Indian languages to produce reasonably good Web content in their own language, even if they have no experience in writing for publication. Such authors with professional knowledge in a variety of fields can quickly contribute to the creation of significant volumes of content, particularly if there is some help in the form of copy-editing. Some of the tools mentioned above involve the use of roman script keyboards and other such practices considered blasphemous in certain language communities concerned with the "independence" of their language. The objection to the use of other scripts is probably a natural extension of the prohibition on the use of words, speech sounds from other languages and the graphemes associated with them. These imports are considered threats to the "purity" of the language. However, it is the "openness" of a language as practiced by a community, rather than its purity, that decides how good that language is in absorbing new vocabulary and concepts. Learning science and technology becomes very difficult in a language that does not absorb new vocabulary and concepts easily.

The absence of a widely adopted text input mechanism affects not only the writers who can create content but also those who search and use information found on the Web. This loss cannot be substituted by poor translations en masse of Wikipedia articles from English. Such practices may increase the number of articles in a language, but cannot be expected to contribute to an increase in "good articles" (Good_articles 2014). Authoring Web content for the use of a specific language community, taking into account the local context is very important. Asking the residents of Tamil Nadu to dial 911 if they think they are having a stroke is not the only type of fault you encounter in articles written for someone else! A common problem with an article that has been "mechanically" translated from English to an Indian language is that it is usually at the wrong level for the readers. The translator should really modify the source article before translating it, so that it suits the needs of the target community well.

\section{The problem of search}

An experienced searcher is often able to ferret out more information from the Web than a naïve user. Some training in searching the Web is even more essential for the person looking for information in a language other than English, because so much less of web content is accessible to him; he needs a search procedure that has a high degree of "recall" so that he does not miss any of the significant content that is there. Using a search engine to search words or word patterns in an Indian language is surely not very easy for naïve users as of now. Specialized search engines could help. The effectiveness, ease of use and other qualities of available specialized search engines merits study.

\section{The human machine interface}

The fact that computers are programmable machines has brought the blessings/curse of great versatility. Hence, the modern laptop can be useful to authors, types-setters, photographers, video makers, game players, statisticians and so on and, by the way, to 
high school students! It is not surprising that a machine designed to perform so many different functions fails to meet two requirements of any student device - ease of use and simplicity of the interface. Any device like a tablet meant for use by school students cannot be based on a 'design by a committee'. It has to have the stamp of an able designer. It should not be expected to meet a lot of needs, but be very good in meeting a few primary needs. eBook readers demonstrate the value of simplicity. Some of them use e-ink displays focusing on text reading than on video etc. They focus on book reading at the cost of interaction. They use slow-speed CPUs and demonstrate an ability to last a month or more on a single charge. They are light, rugged and are relatively low in cost. eBook readers cannot be the answer for a single device that meets a student's needs, but they set a standard in simplicity of design and ease of use.

Ease of use of a device in the hands of students in a given setting is not something that can be predicted by a set of experts in advance. Nor can it be ensured by employing the very best of engineers to design the device. Ease of use has to be one of the major design goals and has to be achieved by having a right mix of engineers, designers and teachers in the team creating the device. Ease of use has to be tested for during the evolution of the design; user feedback should be used effectively by the designers to remove any identified flaws.

\section{Ruggedness, repairability, and technical support}

Warschauer and Ames (2010) are academics in the education field; but their paper gives surprisingly good attention to the issue of how frequently devices got out of service, what service was required to re-commission them, and what service was in fact available. Champions of proposed devices sometimes forget the life-cycle cost of an electronic device in a student's hands. It is not the purchase price alone that matters, but the total life-cycle cost. Apart from cost is the sense of loss, sense of guilt and disappointment that a student experiences when a device is broken, lost or damaged.

\section{The economic context of secondary education in India}

Linden (2012), Page 135) indicates the scale of public expenditure in Indian Secondary ${ }^{j}$ Education. The expenditure in government funded schools and government aided schools averages Rs. 10250 per year per student (2007-08 figure in terms of the value of the rupee in 2004-05), roughly equivalent to US \$224. Again, as per Linden (2012), page 135), no fees were paid by $74 \%$ of students enrolled in Government funded schools, and by $54 \%$ of those enrolled in Government aided schools; while those enrolled in private schools paid an average of Rs. 3375 per year (roughly equivalent to US \$ 74). It is worth comparing the cost of data plans from cellular service providers (Rs 250 per month) reported earlier with the total annual school fee reported here. This indicates how expensive Internet access is when it is provided over the cell phone network.

(Sankar (2011), Page 5) reports that 35\% of secondary schools and 36\% of the senior secondary schools were owned, financed and managed by purely private sector. The others were either government run or financially aided by government grants. (Sankar (2011), page 37) also notes that $81.4 \%$ of secondary school students attend schools funded or aided by government, as per 2007-2008 figures. 
The percentage of students depending upon government funded or governmentaided schools varies from $60 \%$ to almost $100 \%$ over the twenty nine states of India. (Sankar (2011), page 38) lists the percentages in each state.

\section{Mobile internet revenue per customer}

(TRAI 2011) provides authentic information about usage of Internet access over the cellular network. As per this document, average revenue per user (ARPU) per month by end of March 2011 was Rupees ${ }^{k}$ (Rs.) 100 from GSM users and Rs. 66 from CDMA ${ }^{1}$ users; both figures cover revenue from voice as well as other services for all users.

Revenues from Mobile Value Added Services (MVAS) were approximately Rs. 11/ month; $60 \%$ of this, being about Rs. 7, was from SMS (Short Messaging Service, that is, text messaging). Internet related services earned only $9 \%$ of all MVAS revenues, and hence were approximately Rs. 1/month per subscriber.

Major uses of the SMS services were: Requests for ringtone downloads, seeking information like news, cricket scores, astrological predictions, subscribing to jokes and accessing other such services (TRAI 2011). This situation is not changing dramatically. A Report by the Press Trust of India, PTI (2012), quoted by the Economic Times gave information about the situation as of end-March 2012. It quotes a study done by the IAMAI $^{\mathrm{m}}$-IMRB ${ }^{\mathrm{n}}$. Table 2 presents relevant information.

Of the Rs. 24 per month spent Mobile Value Added Services (MVAS), 27\% went into ringtones, 17\% into SMS based applications; mobile apps took 10\% while games took $8 \%$. So, mobile apps usage was less than Rs. 2.5 per month. The report predicted that ARPU will increase by $5-8 \%$ over the coming years.

So, here is the reality: The average Indian user did not spend the equivalent of even one-tenth of a U.S. \$ per month on mobile apps by the year 2012! Commercial costs are too frightening to such users, and so most of them completely avoid Web access over the mobile phone, which is in principle so readily available.

The economic context presented above gives an indication of what needs to be addressed in regard to technology support for education at the secondary school level.

\section{Challenges to be faced \\ Affordable access}

What is the best way for a school to make computers and Internet access available to its students? Installing PCs owned and managed by the school? Or, making WiFi available on the premises and using a variety of means to make tablets or smart phones available to students? There may not be a unique solution to all Indian schools, but it is worth discussing available options for extending Internet access to rural schools. Pun (2002) describes an interesting experience in Nepal in using WiFi as a backbone of a

Table 2 Average revenue per cell phone user in India, 2012

\begin{tabular}{ll}
\hline Item & Amount \\
\hline Number of mobile Internet users in India & 48 Million \\
Average revenue from GSM users & Rs. 96, roughly US\$ 1.76 \\
Average revenue from CDMA users & Rs. 73, roughly US\$ 1.34 \\
Average user spend on MVAS & Approximately Rs. 24 per month, that is 44 US Cents \\
\hline
\end{tabular}


rural network as well as the distribution mechanism. Raman and Chebrolu (2007) and Surana (2009) have described other experiences in using wireless techniques for developing countries. Further, the National Optical Fibre Network of India (NOFN), when it becomes fully operational would make fibre optic access to Internet in 250,000 gram panchayats ${ }^{\circ}$; Ilavarasan et al. (2014) offer a detailed description of this network along with a discussion of delays in its implementation. Schools and public libraries wishing to offer WiFi facilities at their premises should be able to use this network. Several countries have Universal Service Obligation Funds to provide support to efforts to take communication to rural areas. The (Department of Telecommunications 2004) describes the Universal Service Obligation Fund of India which disbursed Rs. 31 Billion in 2010-11 (roughly equivalent to 687 million US Dollars). Such funds, in principle, can pay for school use of WiFi in rural areas; in fact NOFN is funded by the Universal Service Obligation Fund of India.

Providing WiFi access through public libraries might be a very practical approach to serving users in rural areas including school students. They serve readers in different age groups and with varying backgrounds. Unlike many schools, they do not ban the use of cell phones and tablets. Schools often ban cell phones and tablets, considering them to be a distraction in the school environment; Goswami and Premkumar (2014) have studied this ban in the Indian context. Public Libraries can go beyond providing WiFi access; they can serve as centres for spreading skills and knowledge in regard to using the Internet for locating information. Free usage of Internet facilities can be limited to specific domains such as .edu, .ac.in, and gov.in, to avoid undesirable uses. Given free access to the Web, rural Internet can play a major role in driving a knowledge revolution.

\section{Training}

Human resources and managerial abilities are at least as important as equipment and software in the context of extending Internet facilities to schools. The researcher has found from visits to schools that they find it relatively easy for them to get one-time grants to buy a set of PCs and a server or two. However, the annual expenditure for maintenance and software upgrades is usually unavailable. Expertise is usually unavailable to block access to undesirable websites by students and staff. Anti-virus protection is often missing. As a result, schools prefer to keep PCs locked up.

Currently, schools hire temporary staff on an ad hoc basis to provide technical support. Usually, these recruits are without formal training but are keen to learn on the job. By the time they learn enough to do a decent technical support job, they move off to nearby big cities to better paid jobs in the IT industry. It is, therefore, essential to train regular staff members and give them technical skills necessary to keep equipment running; it is also necessary to ensure that such trained staff will be stable in school employment.

A related problem is teacher training. What should they teach and how? Where can they learn it themselves in the first place? A major initiative by Intel (2007) has trained over a million school teachers in the use of computers in India. However, we cannot expect one such program alone to offer all computer-related training required by the staff and teachers of all schools. 


\section{Content creation in students' mother tongue}

The discussion on the difficulty of finding adequate content in students' mother tongue raises the question of what should be done to improve the situation. Encouraging and supporting those who are willing to create eBooks in appropriate languages would obviously be valuable. Public funding of such eBooks as well as financial rewarding of their creation can result in making these books available free of charge on the Web, positively impacting a huge number of students and other readers.

The encyclopaedia format is valuable for making information available on demand, in small units. A Wikipedia in the student's own language, written with the local context in mind, and written at the right level of complexity would be a valuable tool for informal sharing of knowledge. Equally important might be the stimulation of the use of indigenous languages for informal communication and social networking. It would be ideal if society accepts the use of the Roman script as an optional script for communication over the Internet. This researcher believes that the use of the Roman script would have a positive effect on students using their own language over the Internet.

\section{Conclusions}

It is common to see defence ministers and army chiefs declare that the man behind the machine is the major determinant of victory in combat. It is important to recognize, similarly in education that teachers, librarians and technical support staff are critical to success in integrating technology into education. Ambitious plans to use technology in education should use a competence building approach rather than the "cargo cult" approach described by Gilbert et al. (2013).

The commercial world is primarily focused on selling international standard equipment at international prices as the bulk of easy profits lies in such sales. In many countries, depending on only commercial initiatives could leave up to $80 \%$ of learners without the benefits of computers and the World Wide Web. This has been borne out in the Indian context by earlier discussions in this paper on the use of English and other languages over the Web. Focus on rugged, low cost equipment designed for sustainable use in the local environment is very important to serve rural learners. Creating content in their languages, integrating the use of computers and access to the Web into the curriculum are equally important. Major projects in these areas can succeed only when a large number of teachers are trained and motivated to use the new technology.

Cost of access makes it very difficult to depend only on cellular technology to take the Internet to learners all over the country. Public funding of access to the Internet over WiFi from public libraries and schools is worth serious consideration.

The researcher hopes that this paper would contribute to readers gaining a balanced perspective on the potential of the Internet in education in developing regions of the world.

\section{Endnotes}

${ }^{a}$ The List of Abbreviations near the end of the paper provides definitions.

${ }^{b}$ Figures quoted in this paper are rounded off if the significance of the number is not altered by the approximation. 
${ }^{c}$ Telephone density or teledensity is the number of telephone connections for every hundred individuals living within an area.

${ }^{\mathrm{d}}$ Users are defined by (TRAI 2012) as subscribers who pay directly, as well as those who do not pay directly but have access as a member of the household, or from work or school.

${ }^{\mathrm{e}}$ Readership covers the number of persons reading a copy of the daily irrespective of whether they bought it, and is to be distinguished from the count of subscribers.

${ }^{\mathrm{f}}$ This usually gives only 20 minutes of backup power and cannot last the usual length of power cuts in a country like India. Its primary use is to protect the PC from damage arising from frequent power cuts.

${ }^{g}$ This term is used here to denote information other than what is in text books.

${ }^{\text {h}}$ Global System for Mobile Communications.

${ }^{\mathrm{i}}$ This video also asks listeners to call 911 in case they experience signs of stroke!

indian nomenclature identifies grades IX and X as the ones offering secondary education and grades XI and XII as the ones offering higher secondary education.

${ }^{\mathrm{k}}$ The Indian Rupee in 2011 was roughly equivalent to US \$ 0.0217 .

${ }^{\mathrm{l}}$ Code division multiple access (CDMA), a channel access method used in some mobile phones.

${ }^{\mathrm{m}}$ Internet \& Mobile Association of India.

${ }^{\mathrm{n}}$ Indian Market Research Bureau.

${ }^{\circ}$ The gram panchayat is the local self-government organization in a village or small town.

\section{Abbreviations}

IAMAI: Internet \& Mobile Association of India; ICT: Information and Communication Technologies; IMRB: Indian Market Research Bureau; Phablet (a Trademark): A smartphone having a screen which is intermediate in size between that of a typical smartphone and a tablet computer; Teledensity: Telephone density or teledensity is the number of telephone connections for every hundred individuals living within an area; OLPC: One laptop per child.

\section{Competing interests}

The author declares that he has no competing interests.

\section{Acknowledgements}

The author thanks anonymous reviewers whose comments were valuable in making this paper more readable, consistent and compliant to the Journal's standards.

Received: 30 September 2014 Accepted: 1 April 2015

Published online: 18 April 2015

\section{References}

Aakash (Tablet), http://en.wikipedia.org/wiki/Aakash_\%28tablet\%29. Accessed 27 Aug 2014

Andhra Pradesh Government, Hyderabad, India, Education (SE-TRG) Department introduction of English medium with CBSE syllabus in a parallel section from VI class in 6500 identified high schools, Govt. Order No. 76, 10 Jun 2008, http://www.aponline.gov.in/Quick\%20Links/Departments/School\%20Education/Govt-Gos-Acts/2008/ GO.Ms.76.2008.pdf. Accessed 19 April 2015.

S Bhide, "The 3G Auction: what will we do with the extra money?". Macrotrack, National Council of Applied Economic Research 12, 5 (2010)

Census 2001, Data on Language, http://www.censusindia.gov.in/Census_Data_2001/Census_Data_Online/ Language/data_on_language.aspx Accessed 19 April 2015.

Census 2011, Office of the Registrar General \& Census Commissioner of India, Provisional Population Totals: India, http://censusindia.gov.in/2011-prov-results/indiaatglance.html. Accessed 19 April 2015.

A Chaurey, M Ranganathan, P Mohanty, "Electricity access for geographically disadvantaged rural communities technology and policy insights". Energy Policy 32, 15 (2004)

Department of Telecommunications, Government of India, "Universal Service Obligation Fund of India" (2004), http://www.usof.gov.in/usof-cms/home.jsp. Accessed 19 April 2015.

L Gilbert, G Wills, O Sitthisak. "Perpetuating the cargo cult: Never mind the pedagogy, feel the technology", International Computer Assisted Assessment (CAA) Conference, Jul 2013, (Southampton, UK), http:// caaconference.co.uk/wp-content/uploads/Gilbert_caa2013 submission.pdf. Accessed 19 April 2015.

Good_articles, http://en.wikipedia.org/wiki/Wikipedia:Good_articles: Good_articles. Accessed 27 Aug 2014 
I Goswami, R Premkumar, "The ban on mobile phones in the schools in India: a probe to augment efficacy in policy execution". Int J Phys Soc Sci 4, 1 (2014)

Heart and stroke foundation's tamil video on the warning signs of stroke, uploaded in 2007, https://www.youtube.com/ watch?v=pXSoqZSB788. Accessed 19 April 2015.

P V Ilavarasan, and N Srinivasan, "National Optical Fibre Network of India", LIRNEasia (2014), http://broadbandasia.info/ wp-content/uploads/2014/04/NOFN-India_11-April.pdf. Accessed 23 March 2015.

Intel, Teach Program, case study (2007), http://download.intel.com/education/sections/section2/pdf/casestudy_india_ teach-f-scrn.pdf?iid=teach+india. Accessed 20 April 2015.

IRS Q4, Indian Readership Survey, HANSA Research, Published on website of the Media Research Users Council (MRUC) (2012), http://mruc.net/sites/default/files/RS\%202012\%20Q4\%20Topline\%20Findings.pdf. Accessed 19 April 2015.

K Keniston, D Kumar, "The four digital divides" Online erişim21 (2003): 2010, http://web.mit.edu/ kken/Public/PDF/ Intro_Sage_1_pdf. Accessed 19 April 2015.

A Krishna, "Making it in India: examining social mobility in three walks of life". Econ Pol Wkly 48, 49 (2013)

M S Krishnan, S Ramani, in Chapter 10: Snapshots Of The Internet Around 2000, An Asia internet history - second decade (1991-2000), Kilnam Chon (Chief Ed.) (SNU Press, 2015), https://sites.google.com/site/internethistoryasia/ book2. Accessed 19 April 2015.

M Kumar, Impact of the Evolution of smart phones in education technology and its application in technical and professional studies: Indian perspective, international journal of managing information technology (IJMIT) Vol.3, No.3, Aug 2011, doi:10.5121/ijmit.2011.3304 39, http://arxiv.org/ftp/arxiv/papers/1109/1109.0937.pdf. Accessed 19 April 2015

T Linden, Secondary Education, Chapter 12, IDFC Report Secondary Education India 2012

A S Mankotia, "Spectrum auction: Bharti Airtel, Vodafone India, Idea Cellular commit about Rs 85,000 crore to government", Economic Times, 27 Mar 2015, http://economictimes.indiatimes.com/industry/telecom/spectrumauction-bharti-airtel-vodafone-india-idea-cellular-commit-about-rs-85000-crore-to-government/articleshow/ 46709981.cms. Accessed 19 April 2015.

M Meeker, KPCB, Internet Trends, D10 Conference, 5/30/2012, http://www.scribd.com/doc/95259089/KPCB-InternetTrends-2012. Accessed 19 April 2015.

A Mukherji, Times of India Report, 2 crore Indian children study in English-medium, Mar 2, (2012), http://timesofindia. indiatimes.com/india/2-crore-Indian-children-study-in-English-medium-schools/articleshow/12105621.cms. Accessed 20 April 2015.

N Negroponte, "No lap un-topped: digital inclusion from the bottom up", Public Sector Technology \& Management, December 2006, pp 25-29 (2006), http://unpan1.un.org/intradoc/groups/public/documents/apcity/ unpan046328.pdf. Accessed 20 April 2015.

Press Information Bureau, Government of India, "President Unveils Aakash Version 2.0 Tablet on National Education Day", November 11, 2012, http://pib.nic.in/newsite/erelease.aspx?relid=88984. Accessed 20 April 2015.

M Pun, Nepal Wireless Networking Project, http://nepalwireless.net/. Accessed 20 April 2015.

A Puri, "English Speaking Curse", English is a source of anxiety, even despair, for its have-nots, Outlook Magazine, March 24, 2008, http://www.outlookindia.com/article/English-Speaking-Curse/237015. Accessed 20 April 2015.

B Raman, K Chebrolu, "Experiences in using WiFi for rural internet in India". Communications Magazine, IEEE 45, 1 (2007)

PTI Report, 4 Jul, 2012, Article in the Economic Times, "Mobile VAS market may grow to Rs. 33,280 crore by 2013: study", 4 July 2012, http://articles.economictimes.indiatimes.com/2012-07-04/news/32537173_1_mobile-vas-marketmvas-arpu. Accessed 20 April 2015.

R Sadanha, "English heart, Hindi heartland: The political life of literature in India" (University of California Press, 2012), http://www.academia.edu/962297/English_Heart_Hindi_Heartland_The_Political_Life_of_Literature_in_India. Accessed 20 April 2015

D Sankar, 2011, Participation in India: An Analysis of the NSS 64th Round Data, Report No. 33, Discussion Paper Series, South Asia Development Unit, World Bank, http://www-wds.worldbank.org/external/default/WDSContentServer/ WDSP/BB/2011/02/16/000333038_20110216230633/Original/593690Revised010inOIndia1NSS1Jan28.docx. Accessed 20 April 2015.

S Shanbhag, D Rao, R K Joshi, "An intelligent multi-layered input scheme for phonetic scripts", Proceedings of the 2nd international symposium on Smart graphics (ACM, 2002).

RMK Sinha, A Raman, "A modular data terminal for Indian languages". ACM SIGGRAPH Computer Graphics 14, 1-2 (1980)

S Surana, Designing sustainable rural wireless networks for developing regions, PhD dissertation (University of California, Berkeley, 2009)

Telecom Regulatory Authority of India (TRAI), Telecom Sector in India: A Decadal Profile (2012), http://www.trai.gov.in/ WriteReadData/Publication/Document/201304121052403536675NCAER-Report08june12.pdf. Accessed 20 April 2015.

Telecom Regulatory Authority of India (TRAI), The Indian Telecom Services Performance Indicators January - March, 2013, http://www.trai.gov.in/WriteReadData/WhatsNew/Documents/Indicator\%20Reports\%20-01082013.pdf. Accessed 20 April 2015.

Telecom Regulatory Authority of India (TRAI): Mobile Value Added Services (MVAS), Consultation Paper No 5/2011, 21st July, 2011 http://trai.gov.in/WriteReadData/WhatsNew/Documents/Indicator\%20Reports\%20-01082013.pdf. Accessed 20 April 2015

P Thornton, C Houser, "Using mobile phones in English education in Japan". J. Comput. Assist. Learn. 21(3), 217-228 (2005)

Times of India, Indiaspeak: English is our 2nd language, Mar 14, 2010, http://timesofindia.indiatimes.com/india/ Indiaspeak-English-is-our-2nd-anguage/articleshow/5680962.cms. Accessed 20 April 2015. 
W3Techs, Service provided by Q-Success, A-2344 Maria Enzersdorf, Austria, http://w3techs.com/technologies/overview/ content_language/all. Accessed 20 April 2015.

M Warschauer, M Ames, Can one laptop per child save the world's poor? J. Int. Aff. 64, 1 (2010)

M Warschauer, Reconceptualising the digital divide, First Monday, [S.I.], Jul. 2002, ISSN 13960466, http://journals.uic.edu/ ojs/index.php/fm/article/view/967/888. Accessed 20 April 2015.

M Yerushalmy, O Ben-Zaken, "Mobile phones in Education: the case of mathematics". (The Institute for Alternatives in Education, University of Haifa, 2004)

\section{Submit your manuscript to a SpringerOpen ${ }^{\circ}$ journal and benefit from:}

- Convenient online submission

- Rigorous peer review

- Immediate publication on acceptance

- Open access: articles freely available online

- High visibility within the field

- Retaining the copyright to your article

Submit your next manuscript at $>$ springeropen.com 